\title{
交代作用の伝播機構
}

\author{
飯山敏 道* \\ Mechanism of Propagation of Metasomatic Reaction
}

Toshimich IIYAMA

\begin{abstract}
After a brief retrospect on the developement since middle 1950's of studies on metasomatic process, the paper deals with some recent results of experiments aimed to observe the mechanism of propagation of the metasomatic material tranfer in silicates. It is shown that "relict" minerals often participate in the metasomatic reaction. The situation was demonstrated in natural pyroxene skarn transforming into garnet skarn, by alteration experiments of alkali feldspars and of rhyolitic rock. It is pointed out that the glass phase in rhyolite remained as glass at experimental temperatures as low as $200^{\circ} \sim 300^{\circ} \mathrm{C}$ and change its composition by $\mathrm{Na}-\mathrm{K}$ exchange reaction with aqueous solution.

Another experimets showed that the metasomatic reaction propagate to the interior of the crystal through the infiltration of the fluide through cleavage and dislocation lines. The observed reaction rate is about 1000 times greater than that estimated according to a model in which the exotic element is fixed on the surface layer by ion exchange and then by solid state diffusion in the crystal.
\end{abstract}

\section{I. 地殼における物質移動}

岩圈で起っている地学現象はすべて物質の移動 を伴っていると言っても過言ではない。堆積作用, 大断層, 大褶曲, プレートの運動等は, その移動 距離や物質量の規模において, 想像を絶するもの がある場合がある。また, マグマの貫入, 賁出等 は地殼下部又はマントルから地殼中〜浅部ない し，地表への物質移動の代表的なものである。 これに反し, 変成作用に伴ら物質移動が, 鉱物 脈，鉱床の形成，あるいは，地熱水による岩石の 変質に伴う移動は規模の点では, 上記の諸過程よ りはるかに小さい。しかし, この現象は, 岩石又 はマグマに含まれていた造岩元素がこれから分れ て水その他の流体に溶けて運搬され, 他の岩石に
再配分されると言う点が他の過程と異る。また， 有用金属の濃集もこの現象によって起ることが少 くない。研究者の注意をひいている理由の一つで ある。以下用語を簡単化するため, この移動形態 を交代作用と言うことにする。

変成作用に伴って物質の移動が起ると言うこと は古くから言われていた。このことがかなり本当 らしいと思われるようになったのは，1914年に ESKOLA が Finland の Orijärvi 地方の変成作 用の研究で指摘した時からである。しかし当時は, 兰の機構に関する見解は明らかでなく, “交代作 用”と言えば，何か神秘的な臭いを感ずる人も少 くなかった。現在でも，この傾向が若干残ってい る。後述するような理由で, 変成作用に伴って, 大規模な交代作用が起はことはむしろ少く，この

\footnotetext{
* 千葉大学理学部 Faculty of Science, Chiba University
} 
ことが一層研究者をして半信半疑の状態にしてい るのであろう。

交代作用についての理論は，1940年代に入って KORZHINSKII や THOMPSON によってその緒口 が示され, その後, この過程に関する研究はかな り発展している。

筆者は1950年, 坪井誠太郎先生から卒業論文の テーマとして“丹沢山塊の石英閃緑岩に関連する 交代作用”を戴き, 一年間五里霧中で, 若干の観 察と考察を行った後, この問題から離れていた。 幸いにも，1962年以降この問題の実験的研究に従 事することが出来今日に到っている。数年前まで は, 主として化学平衡の面からこの過程を観察し て来た。最近漸く, 鉱物と水溶液間の反応がどの ような機構で進行し, 最終的には化学平衡に達す るのかについて, 若い研究者の方々と若干の観 察, 考察を行うようになった。本稿では, このこ とについて記すこととする。

\section{II. 交代作用の機構と構造地犋学的条件}

砂岩, 頁岩をはじめとする種々の岩石が変成作 用をうけて，その鉱物組合せを変える時に起る反 応には，岩石を構成している鉱物粒の粒間間隙に 存在している水が大きく関与している。この水分 の量は極めて少いが, 鉱物の粒間間隙を連結して, network を形成している。鉱物 (A) と接してい る水（気体，液体を問わない）梳物の一部を溶 かす。この時, 鉱物の構成成分閒の比と, 溶出寸 る成分間の比は一般に一致しない。溶出した造岩 成分は間陌水の network 内を抎散によって移動 し, 他の鉱物 (B) と接する。この時鉱物 (B) でも（A）と同様の溶出現象が起っており，(B) の表面には溶出しなかった成分の層が残ってい る。この残存成分と溶液中を移動して来た（A） の成分が反応して, 新しい鉣物を形成する。変成 作用で, 緑泥石と絹雲母が隣接しているとは限ら ないにも拘らず黒雲母を生ずるのもこの機構によ る。

粒間間隙のネットワークの拡りは岩石の状態に よって異るが，一般にはあまり大きくない。变成 作用をうけた凝灰岩中の石灰岩岩片が，その周縁 数 $\mathrm{mm}$ 時には数 $\mu \mathrm{m}$ だけ, 凝灰岩と反応して
いるにすぎないことがしばしばあるのはこのため である。また変成作用に伴う岩石の総化学成分 は, 多くの場合水分 $\mathrm{H}_{2} \mathrm{O}$ \%を除いては, あまり 変化しないのも, 間隙水の network が大きな搪 りを持たないためである。

若しこの岩石が断層その他による破砕面を持っ ていると様子は全く異って来る。これらの破砕面 に間隙水 network の一端が開き，又破砕面を通 って, 天水, 海水 (多くの場合, 火成岩体の熱そ の他により加熱されている）時には，マグマから 分相した水溶液などが侵入して来る。この通路を 通して, 物質の移動が容易に, かなり大規模に進 む。近年, 注目の的となっている大洋の中央海嶺 付近で発見された深海底熱水鉱床の形成はまさに その好例の一つである。

岩石中に破挽面が生ずると, 物質移動が起り易 くなるもら一つの理由がある。岩石が, 水溶液と 接し, 水溶液が移動しなければ, 溶液の組成はや がて，岩石の鉱物組合せに対応した平衡值に達し て，反応はそれ以上進行しなくなる。反応によっ て気体が生ずる場合には，気体の分圧が平衡值に 達すれば，それ以上反応は進行しなくなる。若し， この溶液や気体が移動し得て, 岩石が常に新しい 溶液と接するような環境に置かれると反応の平衡 は実現されず，岩石の溶液による改変は深く進行 して行く。石灰岩と溶液が接して反応が進行し, かなり大規模なスカルンが形成されることがある 反面，石灰岩中に岩脈が貫入しても，その接触面 に数 $\mathrm{mm}$ 数 $\mathrm{cm}$ の反応縁が形成されるにすぎ ない場合も少くないのは，溶液や気体の逸散路が 開いていたか否かにかかっている。

このように考えると, 交代作用が起り物質の移 動が起らないか, 又その規模の大小は, 化学的側 面の問題もさること乍ら, 構造地質学的条件に支 配されているところが極めて大きいのである。

では, 反応の進行につれて, 既存鉱物はどのよ うに進行して行くのであろらか。

\section{Relict 鉱物についての考察}

岩石中の鉱物がある反応によって別の鉱物に変 化しつつあるが完全に改変されていない状態を示 している時, 改変されていない既存の鉱物をレリ 
クト（relict）鉣物と呼んでいる。

この言葉の中には, relict 鉱物はまだ反応に 参加していないで残っている鉱物であるという 錯覚を与える。果してそうであろうか。
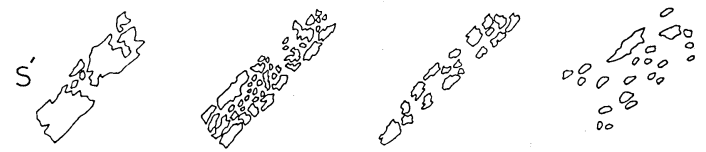

加藤泰浩は修士課程において行った, 岐阜県 神岡鉱物，茂住鉱床の研究中に, 単斜輝石が灰 鉄ザクロ石によって置換されて行く過程を示す 一連の標本を採取した(KATO 1987)。これに ついて彼は反応の進行と，レリクト鉱物である 単斜輝石の組成との関連をしらべた。反応の進 行につれて，単斜輝石は細粒化して行くが，幸 い同一粒から派生した小粒は同時消光をするの で，源鉱物の輪郭を推定することができ，何％ の源輝石が灰鉄ザク口石に変ったかについての 概測が可能であった（第1図）。この反応に伴っ て, 残留している単斜輝石はもと $\mathrm{Di}_{20} \mathrm{Hd}_{75}$ の ものであったのが次第に鉄の含有量の少いもの に変化し, 最終的には, $\mathrm{Di}_{70} \mathrm{Hd}_{30}$ 前後のもの になっている。(第 2 図)。このことは, 最初, 酸素フュガシティーが低い環境下で形成された 単斜輝石が，その後流入した酸素フュガシティ 一の高い溶液が，その $\mathrm{Fe}^{2+}$ の一部を酸化し， 灰鉄ザク口石となり, 溶液の酸素フュガシティ 一を下げ，灰鉄ザク口石，単斜輝石固溶体，溶 液の間の平衡を実現するようにその組成を変化 させて行ったことを示しているものと解䣋され る。Relict である単斜輝石も, 終始この反応に 参加していたと考えられる。

これと同様な現象は, 低温においてカリ長石 を熱水溶液と反応させる時 (LAGACHE 1965) にも見られた。又白木亮司が行った。石英粗面 岩と海水との反応においても見られている。 （白木 1987）。何れの場合にも，溶液の組成は 反応開始後急速にその組成を変え，固相中には 大量に残存する源固相と極微量の新生鉣物と反 忘によって組成が変った溶液との間で準平衡状態 が成立し, 反応はそれ以上進行し難くなる。溶液 を更新すると同様の変化が急速にくり返されて行 く。カリ長石又は石英粗面岩のような比較的高温 で安定な釷物, 又は鉱物組合せを, $200^{\circ} \mathrm{C} \sim 300^{\circ} \mathrm{C}$ のような低温で安定な鉱物組合せに変化させるの は，低温であるため反応速度が小さいので困難で
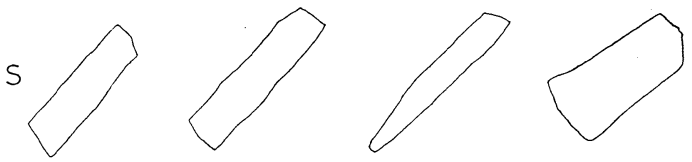

$\frac{S^{\prime}}{S} \quad 0.68$ 0.51

0.45

0.20

第 1 図神岡鉱山, 茂住鉱床中の輝石スカルンのざ くろ石化を示す薄片のスケッチ（加藤泰浩 原図)

上段は同時消光をする単斜輝石小粒の集合状態を 示す.下段は上段の図から推定した源輝 石の形状 $\mathrm{s}^{\prime} / \mathrm{s}$ は, 上段の輝石粒と下段の推定源輝石の面積比 を示す.

スケールは $2 \mathrm{~mm}$ の長さを示す.

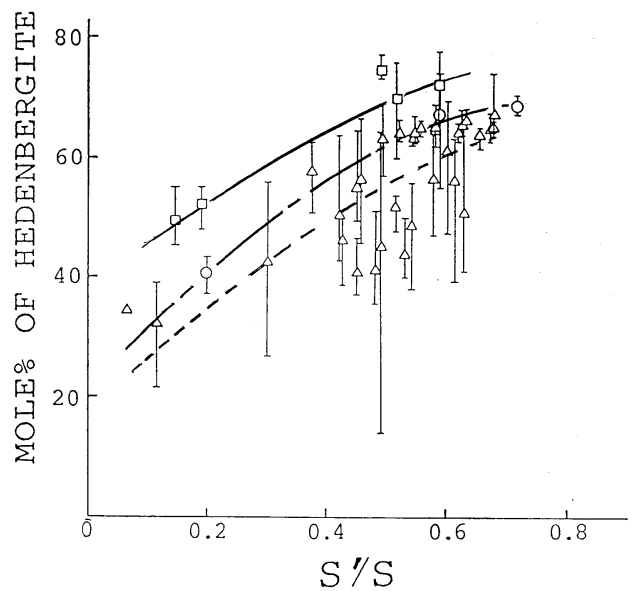

第 2 図第 1 図で求めた $\mathrm{s} / \mathrm{s}$ 比と残留単斜輝石の組 成の関係.

あると言うことも一つの理由である。しかし，殆 んどの実験では溶液が更新されないと言うことも 大きな原因になっている。

ここで, 更に指摘したいことは, 石英粗面岩中 のガラス相も立派に 1 相としてこの準平衡に参加 しており, 実験中ガラス相の失透現象すら容易に 見られないことが多いことである。更に，このガ 
ラス相は溶液と，次節で述ぶるイオン交換反応を 起して組成を変えている。もっとも，このこと は, ガラスの組成にも左右されて抢り, 一般に $\mathrm{Al}_{2} \mathrm{O}_{3}$ の量が多い程失透し難くなる。このこと は, 工業ガラスの化学耐性について言われている こととも一致する。

\section{IV. 珪酸塩鉱物一熱水溶液間のイオン交換 の伝播機構}

造岩鉱物は，熱水溶液と接した時，これと反応 して，別種の鉱物を形成することが多い。しか し, しばしば, 鉱物中の一成分を溶液中に放出す るかわりに，溶液から他の元素イオンをとりこみ 同型置換を実現する。アルカリ長石（WYART＆ SABATIER 1956; ORVILLE 1963; IIYAMA 1964; LAGACHE 1980), 斜長石 (WYART \& SAbatier 1.961; IIyAma 1966; ORville 1972), 単斜輝石（飯山活か 1980），雲母（IIYAMA 1964； JSCHLIEN 1980）かんらん石 (SCHLIEN et al. 1970) 等, その例はかなり多 く, またこの時の溶液と固溶体の組成の平衡関係 も求められている。

これらの研究は, イオン交換反応が起ると言う 事実の確証と，平衡関係の決定を目的としている ため，この交換平衡がぞの位の速さで，どのよう な機構で伝播するかについては解っていなかっ た。しばしば考えられるのは, 結晶の表面でイオ ン交換が起り, 表面に固定されたイオンは, その 後固体拡散によって, 結晶内部に進行すると言う 機構であった。

若しこのような機構で, イオン交換反応が進行 するとすれば，実験温度である $600^{\circ} \mathrm{C}$ 前後の低 温ではその進行は極めておそいと考えられる。高 温で, 玨酸塩鉱物について測定された拡散係数 を, その活性化エネルギーに基いて $600^{\circ} \mathrm{C}$ 前後に 外挿すると $10^{-15} \sim 10^{-16} \mathrm{~cm} / \mathrm{sec}^{2}$ のオーダーとな る。すなわち $\mu \mathrm{m} /$ 年の進行速度を示すはずであ る。

単斜輝石およびかんらん石について行った実験 （加藤ほか 1987）は, 輝石, かんらん石何れの 場合にも， 7 日間程度の熱水溶液による処理で, この反応は表層から $20 \mu \mathrm{m}$ に及ぶ深さまで進行
し，これから得られる見掛けの拡散係数は $10^{-12}$ のオーダーすなわち, 固体扡散による場合の 1000 倍位速いことが解った。更に, このイオン交換反 応実験を行った後の結晶断面の組成分布をみる と，交換反応を起した部分と，まだ起していない 部分の境界が非常に sharp である。(第 3 図) ま た，鉄分を多く含む鉱物を $\mathrm{Mg}$ 含む溶液と反応 させた時の方が反応の伝播が逆の場合よりも大き いことも判明した。

単斜輝石の場合（第 3 図a）には, 写真で見て も解るように, その䢃開面を通路として熱水溶液 が浸透して, イオン交換を起し, 溶液に出た輝石 起源の元素は溶液中に拡散によって移動して行く 機構を思わせる。又このような機構と, 単斜輝石 の固液両相の平衡組成関係は, 輝石の組成 profile が示す sharp な境界をよく説明している。

かんらん石のように明膫な䢃開を示さない鉱物 の実験で見られた組成 profile（第3図b）で は, イオン交換を起した部分と, まだ起していな い部分の境界は比較的 sharp であるが，未交換 部の中にも斑点状にイオン交換が起った部分が点 在しているのがみられる。反応部分の中にも, 同 様に鉄に富んだ斑紋がみられる。これらの斑紋の 分布とその形態はこれが, かんらん石の内部に存 在する dislocation の線を通路として溶液が浸透 してイオン交換を結晶内部に伝播させているこ とを思わさせる。第 3 図 (b) には，イオン交 換を起した部分の斑点分布密度は, 未交換部分 のそれよりはるかに高く，交換に伴って，新に dislocation が誘起されていることを示唆してい る。

䢃開はまだしも, dislocation の線を通して, 溶液が果して浸透し得るものなのか, 興味のある ところであり，現在このことを追及する実験を行 っている。

珪酸塩鉱物中に存在する Si-O 四面体の骨組構 造の中にほんのわずかな量の $\mathrm{OH}$ 基が入ること によって, 結晶中の Si-O 四面体間を結ぶ結合が 弱まり, 結晶の塑性変形の挙動を大きく変えるこ とは近年明らかにされていることである (KRONENBERG and TOLLIS 1984; MACWELL et al. 1985)。この事は，単に鉱物の機械的性質に現われ 


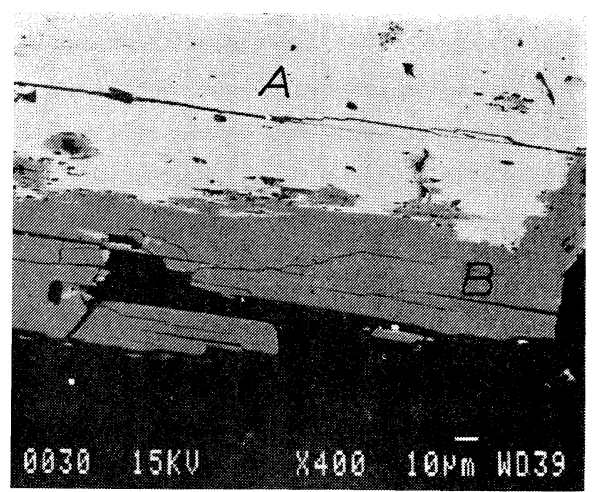

第 3 図 (a)

鉄に富む単斜輝石結晶 $\left(\mathrm{Hd}_{90}\right)$ を $\mathrm{MgCl}_{2} 1 \mathrm{M}$ の水溶 液と共に $600^{\circ} \mathrm{C} 1 \mathrm{~Kb}$ 下で 3 日間処理したものの $\mathrm{Fe}$ $\mathrm{X}$ 線像. 源輝石部 $\mathrm{A}$ と，イオン交換が進み $\mathrm{Mg}$ に富 む輝石となった部分（B）の境界の解明さに注意

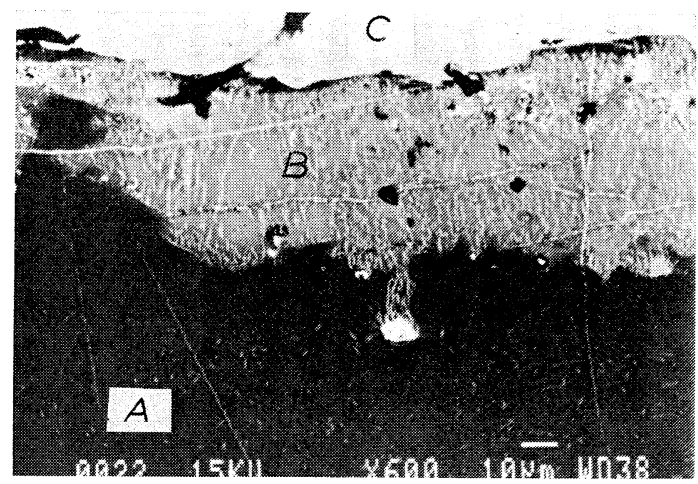

第 3 図 (b)

$\mathrm{Mg}$ に富むかんらん石 (Fo 98) $\mathrm{FeCl}_{2} 1 \mathrm{M}$ 水溶 液および金属鉄と共に $800^{\circ} \mathrm{C} 1 \mathrm{~Kb}$ で 3 日間処理し たものの $\mathrm{Fe} \mathrm{X}$ 線像.

・写真上部の白色部 (C) 汉金属鉄.

・鉄の分布の線状配列に注意.

・イオン交換がまだ進行していない（A）部にも，若 干の Fe に富む線状配列が認められる.

・交換の進んだ（B）部の線状構造の分布密度は (A) 部より高い.

・金属鉄を溶液と共に処理したのは，溶液の Fe 濃 度を常に高く保つためである。鉄は，珪酸塩より

も溶液に濃集する傾向があるためである.

るのみでなく，化学耐性，ひいては，鉱物と水溶 液とけ反忘速度にも影響字及ぼすここは当然考え
られる。 $\mathrm{OH}$ 基が結晶構造中の正規の位置でな い所にどのようにして侵入して来るのか, この 機構の解明は，交代作用を化学反応速度論的な 見地から考究するための基本的な問題とつなが ってがってもいる。

\section{V. 結言}

坪井先生は，御自身で交代作用についての見 解を公にされなかったよらに記憶する。しか し，この現象に対し，常に興味を持たれ，さき に述べたように，卒業論文のテーマとして交代 作用に関連した問題を出されていた。当時は, 交代作用の機構についてはあまり解っておら ずわずかに，RAMBERG（1952）の著書の中 に極く定性的な解説がのせられているにすぎな かった。坪井先生は花崗岩質岩石に見られる混 成作用についても，マグマと外来岩片又は同源 捕獲岩との間の反応を交代作用の面から見るよ うにしばしば言われていた。

それも当時多くの研究者が一連の岩石の分析 值から, Addition-subtraction 図を作って, 何 が岩石に加わり，何が減少したと記述する事を もって事足れりとすることに満足されず，常に 何故この元素は他へ移動せざるを得ないのかと 言うことを追究するよう励ましておられた。そ の頃から40年近い歳月がたち当時をふり返って 見ると，この現象の解明は，他の現象の解明に 比し, おくれてはいるものの, かなり科学らし いものとなって来ている。“現象の機構は, こ れを最も簡単な表現で明快に言えるようになっ た時，本当に理解したと言える”とよく言われ る。交代作用が水，マグマ，気体等の流体を媒 体とする輸送過程であることが解ったことだけ でも大分明快になったが，まだその細部の説明 は明快ではない。途は遠いが見遠しは明るい。

坪井先生の追悼講演会に当って, 交代作用の 最近の研究の一部と問題点を記して, 先生から 受けた御薰陶をしのぶ次第である。 


\section{引用文献}

Askola, P. (1914) : On the petrology of the Orijärvi region southwestern ${ }_{\AA}^{\circ}$ Finland. Bull. Comm. geol. Finlande, No: 40 .

Fonoeilles, M. (1978) : Les mecanisme de la metasomatose. Bull. Miner., 101, 166-194.

HoFMANN, A. (1972) : Chromatographic theory of infiltration metasomatism and its application to feldspars. Amer. Jour. Sci., 272, 69-90.

IIYAMA, J. T. (1964) : Etude de al réaction d'échange d'ions Na-K dans la série muscoviteparagonite, Bull. Soc. franc. Miner. Crist., 87, 532-541.

- (1966) : Contribution à l'étude des équilibres sub-solidus du systéme ternaire orthose-

albite-anorthite á l' aide des réaction d' échange d' ions $\mathrm{Na}-\mathrm{K}$ au contact d' une soluition hydrothermale, Bull. Soc. franc. Miner. Crist, 89, 442-454.

飯山敏道・河村雄行・内田悦生 (1980) : 輝石族，準輝石族一熱水溶液系のイオン交換平衡の諸問題. 日本鉱物学会, 1980年年会講演集.

- (1982)：地殼内部の物質移動と鉱物の性質. 岩鉱，特別号 3 号，291-304.

IIYAMA, J. T. (1984) : Hydrothermal solution-mineral equilibria as a clue for studies of geochemical transport phenomena in the earth's crust, Materials Science of the earth's interior (I. SunAgawA editor), Terra Scientific Publishing Co, Tokyo, 493-513.

KAто, Y. (1987) : Skarn formation and mineralization of the Mozumi deposit, Kamioka mine. Mastrer thesis, University of Tokyo

加藤泰浩・藤本光一郎・飯山敏道 (1987) : 珪酸塩におけるイオン交換反応の伝幡機構, 三鉱学会, 1987年年会講演集.

KorZHINSKII, D, S. (1937) : Mobility and inertness of componenst in metasomatosis. Bull. Akad. Nauk. SSSR. Ser. Geol., No. 1, 35-60.

(1950) : Phase rule and geochemical mobility of elements. Rep. 18 th Sess. IGC., G. B. 1948, Pprt. 2, 50-65.

-and TUllis (1984): Flow strengths of quartz aggregates: Grain size and pressure effecst due to hydrolytic weakning. J. Geophys. Res., 89, 4281-4297.

LAGACHE, M. (1965) : Contribution á l' étude de l'alteration des feldspaths, dans l' eau, entre 100 et $200^{\circ} \mathrm{C}$, sous divers pression de $\mathrm{CO}_{2}$ et application a la synthése des mineraux argileux. Bull. Soc. franc. Miner. Crist., 88, 223-253.

KRONENBERG, A. K. (1980) : Etude experimentale des systémes albite-orthose-NaCl-KCI- $\mathrm{H}_{2} \mathrm{O}$, albiteorthoseanorthite- $\mathrm{NaCl}-\mathrm{KCI}-\mathrm{H}_{2} \mathrm{O}$ á $500^{\circ} \mathrm{C}$ et pression variables $(0,5$ a $2 \mathrm{kbars})$ Mineralisations liées aux granitoides (Z. JoHAHN editor) D. G. R. S. T. and B. R. G. M. 1980, 123-127.

Mackwell, S. J., Kohlstedt, D. L. and PAterson, M. S. (1985) : The role of water in the deformation od olivine single crystals. Jour. Geophys. Res., 11319-11333.

ORville, P. M. (1963) : Alkali ion exchange between vapor and feldspar phases. Amer. Jour. Sci., 261, 201-237.

- (1972) : Plagioclase cation exchange equilibria with aqueous chloride soltion: results at $700^{\circ} \mathrm{C}$ and 2000 bars in the presence of quartz. Amer. Jour. Sci., 272, 234-272.

RAMBERG, H. (1952) : The origin of metamorphic and metasomatic rocks. The Univesity of Chicago Press, Chicago

SCHLien, S., Friedrichsen, H. und Hellner, E. (1970) : Das Mischkristallverhalten des Olivines $450^{\circ} \mathrm{C}$ und $650^{\circ} \mathrm{C}$ bei IKb Druck. N. Jb. Miner. Mh., Jg. 1970, 4, 141-147.

- (1980) : Mg-Fe partitioniing between biotite and a supercritical chloride solution. Contrib. Mineral. Petrology 74, 85-93.

- (1987) : Experimental study on ion exchanges reaction between rhyolitic glass and hydrotheramal solution. Ph. D. Thesis. Univ. Tokyo.

Thompson, J. B. Jr. (1955) : The thermodynamic basis for the mineral facies. Amer. Jour. Sci., 253, $65-103$.

(1959) : Local equilibrium in metasomatic processes. Researches in geochemistry (ABER- 
SON, Ph. Editor) John Wiley \& Sons N. Y. 452-457.

Wyart, J. and SABAtier, G. (1956): Mobilite des ions alcalins et alcalinotérreux dans les feldspaths. Bull. Soc. franc. Miner. Crist. 98, 49-52.

- and-_-(1962) : L' equilibre des feldspaths et des feldspahoides en presence de solutions sodipotassiques. Norsk. Geol. Tiddsskr., 42, 317-329.

-(1965) Réactions des feldspaths alcalins avec des solutions hydrothermales de $\mathrm{CaCl}_{2} \mathrm{C}$. R. Acad. Sci. Paris, 260, 1681-1685.

（昭和63年 3 月 9 日受理） 